\title{
NEPHROSTOMY FOR ACUTE OBSTRUCTIVE RENAL FAILURE IN WOMEN WITH CERVICAL CANCER - IS IT WORTH?
}

D.B. Vale, M.L.A.M. Silva, M. Marangoni, J.C. Torres, W. Cassin, H. Machado, J.F. Bragança. Gynecology and Obstetrics Department, State University of Campinas, Brazil.

\section{OBJECTIVE}

To evaluate outcomes related to nephrostomy in women before and after cervical cancer treatment for acute obstructive renal failure.

\section{METHODOLOGY}

Were included 57 cases of women with cervical cancer IIIB+ and acute obstructive renal failure that have undergone nephrostomy at the University Women's Hospital of Unicamp (Campinas, Brazil), from 2002 to 2018. Two groups were evaluated: before and after radiotherapy treatment (BT and AT). Variables were analyzed by Cox regression (Step Wise selection) and survival by Kaplan-Meier curves and log-rank $(P<0.05)$.

\section{RESULTS}

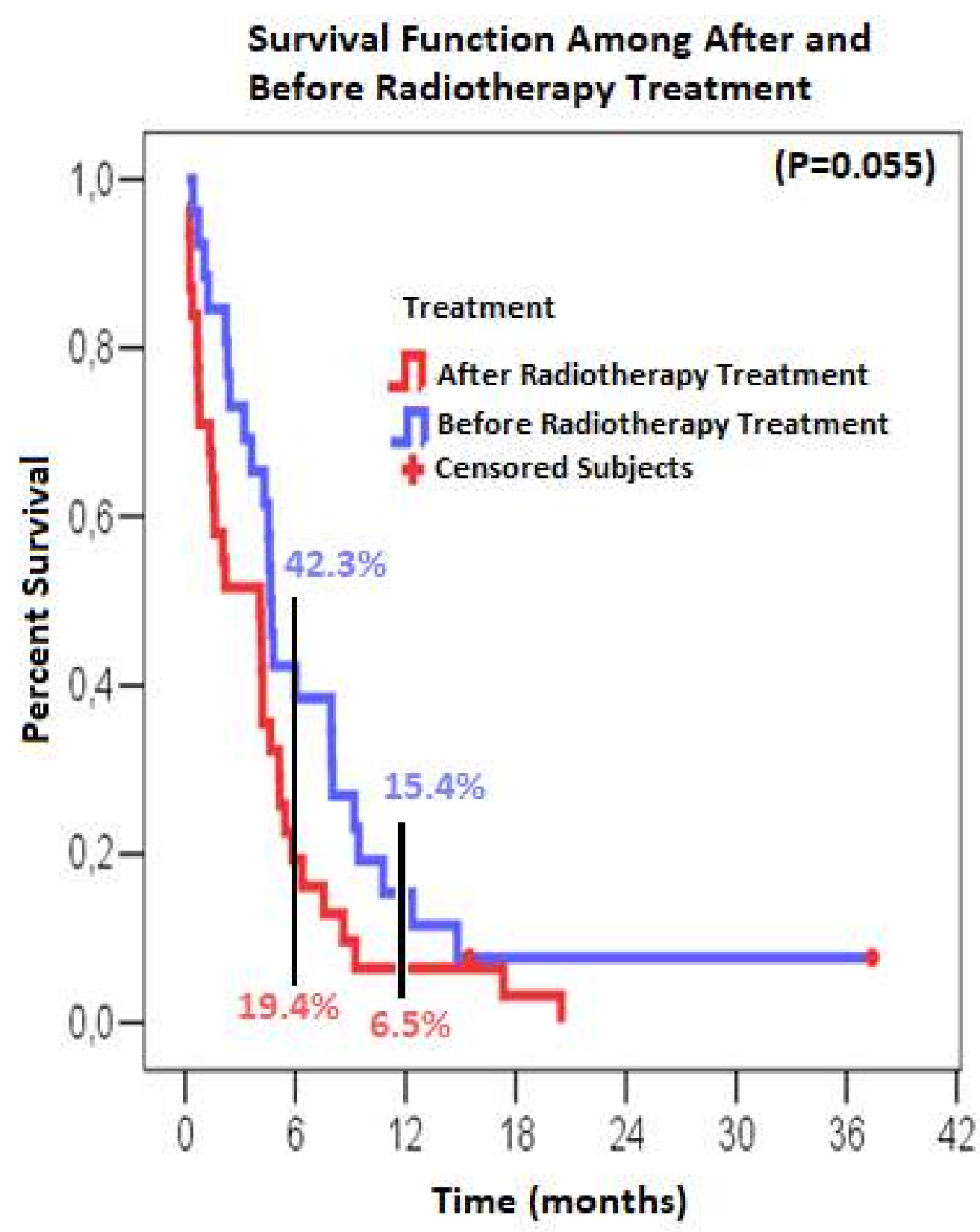

Figure 1. Overall survival in patients with nephrostomy for acute obstructive renal failure in women before and after cervical cancer treatment
Table 1. Descriptive analysis of $\mathbf{5 7}$ nephrostomy for acute obstructive renal failure in women with cervical cancer

\begin{tabular}{|l|c|}
\hline Variables & \multicolumn{1}{|c|}{ Average } \\
\hline Age & 48.05 years (ST 13.28) \\
\hline Body Mass Index (BMI) & $24.9 \mathrm{~kg} / \mathrm{m} 2$ (ST 5.6) \\
\hline Urea Before Nephrostomy & $135.1 \mathrm{mg} / \mathrm{dL}$ (ST 74.82) \\
\hline Creatinine Before Nephrostomy & $8.8 \mathrm{mg} / \mathrm{dL}$ (ST 1.4) \\
\hline Day 1 Diuresis After Nephrostomy & $2723 \mathrm{~mL}$ (ST 2450) \\
\hline Total Hospitalization Period & 25 days (ST 20) \\
\hline sT - Standard Deviation & \\
\hline
\end{tabular}

Table 2. Overall survival influencing factors in multivariate analysis of nephrostomy for acute obstructive renal failure in women with cervical cancer

\begin{tabular}{|l|c|c|c|}
\hline \multicolumn{1}{|c|}{$\begin{array}{c}\text { Analyzed } \\
\text { Factors }\end{array}$} & Categories & P value & Hazard Ratio \\
\hline $\begin{array}{l}\text { Positive diuresis } \\
\text { at the first day } \\
\text { after the } \\
\text { procedure }\end{array}$ & $\begin{array}{c}>3300 \mathrm{~mL} \\
1000-3300 \\
\mathrm{~mL}\end{array}$ & ----- & 1.00 \\
\hline $\begin{array}{l}\text { Body Mass } \\
\text { Index (BMI) }\end{array}$ & $\leq 2000 \mathrm{~mL}$ & $<0.001$ & $6,59(2.54-17.13)$ \\
\hline $\begin{array}{l}\text { Need of a new } \\
\text { New } \\
\text { procedure }\end{array}$ & No & ----- & 1.00 \\
\hline
\end{tabular}

\section{CONCLUSIONS}

Nephrostomy for acute renal failure due to cervical cancer is associated with prolonged hospitalization regardless of the stage of the treatment. Overall survival was low in both groups, but higher in women in the BT procedure. Although nephrostomy might be considered useful in treatment-naive patients with obstructive renal failure, the validity of this type of treatment in the group of women that had already undergone treatment is not yet defined.

\section{DISCLOSURE}

We declare that authors don't have any sponsoring institutions ou financial relationships related to this work. 